\title{
ANALISIS PEMASARAN TELUR DI KECAMATAN TILATANG KAMANG KABUPATEN AGAM \\ (Studi Kasus Peternakan H. Djarasun Mangkuto Kec. Tilatang Kamang Kabupaten Agam)
}

\author{
Rahmat Syafriardi dan Ismet Iskandar \\ Fakultas Peternakan Universitas Andalas Padang
}

\begin{abstract}
This research is aimed to identify marketing policy and and future startegy that should be taken by the business of $\mathrm{H}$. Djarasun chicken husbandry.this husbandry is being chosen because this husbandry is the biggest husbandry in Kecamatan Tilatang Kamang, Kabupaten agam. In this research the writers collected primary data taken from the key informan in the business and secondary data which is taken from related government instituion.

From this research the writers can formulated marketing strategy which is recommended to be held by the company.The startegy is optimizing the company resources and optimizing current market and supported with developing feed milling unit in the company to get lower cost, and optimizing the relationship with their current customers.
\end{abstract}

Keywords: marketing mix, strategy, marketing channel

\section{Pendahuluan}

Dilihat dari jumlah rumah tangga pemelihara ayam ras petelur, kabupaten Agam merupakan daerah dengan jumlah rumah tangga peternak ayam ras petelur yang paling rendah di Sumatera Barat bila dibandingkan dengan daerah tingkat II atau kabupaten lainnya seperti kabupaten 50 Kota yang sudah terkenal sebagai daerah sentra produksi telur ayam ras di Sumatera Barat.

Saat ini pemerintah kabupaten Agam sedang berusaha merintis kawasan sentra produksi telur ayam ras yang terletak di kecamatan Tilatang Kamang. Daerah ini dipilih sebagai kawasan sentra pengembangan ayam ras petelur karena di daerah ini terdapat populasi ayam ras petelur terbesar dibandingkan dengan kecamatan lainnya di Kabupaten
Agam, seperti yang terlihat pada Tabel 1.

Di daerah ini mayoritas peternak adalah peternak skala rumahan dan hanya 4 peternak diantara mereka yang serius menekuni usaha ini dalam skala besar (>10.000).

Seiring dengan terus meningkatnya tingkat permintaan telur ayam ras di daerah ini maka peluang dibukanya usaha serupa sangat besar. Bagi peternak skala besar tentu saja ini menjadi tantangan yang berarti dalam upaya memproduksi dan memasarkan produknya dalam skala yang lebih besar lagi, dan di lain pihak kondisi ini tentu saja dapat memicu munculnya usaha baru serupa yang dapat menjadi ancaman bagi peternak skala besar yang telah lebih lebih dulu eksis di pasar.

Masuknya berbagai pendatang baru tentu saja akan memerlukan sebuah konsep penguasaan pasar 
yang lebih terarah agar peternak yang telah ada dapat lebih berbenah diri dalam menghadapi persaingan nantinya.

Saat ini peternak ayam ras petelur yang terbesar di kecamatan Tilatang Kamang adalah H. Djarasun. Usaha ini dirintis sejak tahun 1983 dan terus mengalami perkembangan dengan jumlah populasi terakhir 30.000 ekor. Populasi ayam ras petelur usaha ini merupakan yang terbesar dan merupakan 37,5\% dari total populasi ayam ras petelur di kabupaten Agam. Seperti yang terlihat pada Tabel 2. Walaupun usaha ini tetap mengalami pasang surut, namun usaha ini dapat terus eksis. Untuk dapat terus bertahan, perusahaan ini harus mampu bersaing dengan pesaing dari dalam Sumatera Barat maupun dari luar Sumatera Barat.

Menurut Swashta dan Sukotjo (1999) salah satu alat untuk menentukan keberhasilan pemasaran adalah kebijakan pemasaran yaitu kombinasi dari empat variabel atau kegiatan pemasaran yang dikenal dengan marketing mix, yakni kombinasi antara produk, struktur harga, kegiatan promosi dan sistem distribusi.

Melihat kondisi usaha dan perkembangan usaha yang ada serta

Tabel 1. Rumah Tangga Ayam Ras Petelur di Kabupaten Agam

\begin{tabular}{|c|l|c|c|}
\hline No & \multicolumn{1}{|c|}{ Kecamatan } & Rumah Tangga & Populasi (ekor) \\
\hline 1 & Tanjung Mutiara & - & 0 \\
2 & Lubuk Basung & 1 & 500 \\
3 & Tilatang Kamang & 10 & 72.500 \\
4 & IV Angkat Candung & 3 & 5.700 \\
5 & Baso & 2 & 1.200 \\
6 & Palembayan & - & 0 \\
7 & Sungai Pua & - & 0 \\
8 & Kamang Magek & 1 & 550 \\
9 & Matur & - & 0 \\
10 & Banu Hampu & - & 0 \\
\hline
\end{tabular}

Dinas Peternakan TK I Sumatera Barat 2003

Tabel 2. Populasi Ayam Ras Petelur Peternak di Kecamatan Tilatang Kamang

\begin{tabular}{|c|l|c|}
\hline No & \multicolumn{1}{|c|}{ Peternak } & $\begin{array}{c}\text { Jumlah Ayam yang } \\
\text { Dipelihara (ekor) }\end{array}$ \\
\hline 1 & H. Djarasun & 30000 \\
2 & H. Agustami & 10000 \\
3 & H. Dt. Rajo Endah & 24000 \\
4 & H. Rajo Balimo & 15000 \\
5 & Farlan & 5000 \\
6 & H. Antoni & 5000 \\
7 & Yeni & 4000 \\
8 & Pendi & 5000 \\
9 & Endang & 5000 \\
10 & Datuak & 5000 \\
\hline
\end{tabular}

Sumber : Cabang Dinas Peternakan Tilatang Kamang 2004 
rendahnya kuantitas telur yang ada di daerah ini, maka penulis tertarik untuk meneliti tentang "Analisis Pemasaran Telur di Kecamatan Tilatang Kamang Kabupaten Agam" dengan mendalami usaha peternakan ayam ras petelur H. Djarasun sebagai studi kasus.

\section{Perumusan Masalah}

Penelitian ini dimaksudkan untuk dapat menjawab permasalahanpermasalahan sebagai berikut:

1. Kebijakan pemasaran seperti apakah yang telah dilakukan selama ini oleh usaha H. Djarasun selama ini dalam melakukan penjualan telur?

2. Strategi pemasaran seperti apakah yang sebaiknya dilakukan oleh peternakan $H$. Djarasun untuk dapat memperluas pasar di masa yang akan datang?

\section{Tujuan Penelitian}

Adapun tujuan dari penelitian ini adalah:

1. Untuk mengetahui kebijakan pemasaran yang telah dilakukan oleh peternakan H. Djarasun dalam memasarkan produknya?

2. Membantu memformulasikan bentuk strategi pemasaran yang sebaiknya dilakukan oleh peternakan H. Djarasun di masa yang akan datang agar dapat terus eksis dan mampu memperluas daerah cakupan pemasaran.

\section{Metodologi Penelitian}

\section{Tempat dan Waktu Penelitian}

Penelitian ini dilaksanakan pada usaha peternakan ayam ras petelur $\mathrm{H}$. Djarasun Mangkuto yang berlokasi di kecamatan Tilatang Kamang Kabupaten Agam. Penelitian ini dilaksanakan selama satu bulan mulai tanggal 2 Februari 2005 sampai 2 Maret 2005.

Penelitian ini dilakukan dengan pendekatan studi kasus. Pemilihan lokasi dilakukan secara purposif, karena lokasi penelitian merupakan usaha peternakan ayam ras petelur terbesar yang ada di Kabupaten Agam serta dinilai memiliki record data penjualan dan sistem penjualan yang relatif lebih baik dibandingkan dengan usaha serupa lainnya di daerah tersebut. Peternakan ini dipilih karena dinilai mampu mengembangkan usahanya dari skala rumah tangga sampai menjadi usaha berskala besar, dan memiliki pengalaman yang baik serta manajemen usaha yang baik pula untuk dapat dipilih sebagai lokasi penelitian.

\section{Pengumpulan data}

Dalam penelitian ini penulis mengumpulkan data primer yang bersumber dari hasil wawancara terhadap informan kunci pada perusahaan yang bersangkutan dengan menggunakan daftar pertanyaan yang telah disediakan dan pengamatan langsung di lapangan. Informan kunci adalah pimpinan peternakan, bagian produksi, bagian keuangan, bagian pemasaran dan pelanggan. Data sekunder diperoleh dari instansi yang berhubungan dengan penelitian yaitu Dinas peternakan kabupaten Agam.

\section{Variabel yang Diamati}

Variabel yang diamati di dalam penelitian ini adalah :

a.Variabel bauran pemasaran, variabel ini digunakan untuk mengetahui kebijakan pemasaran seperti apa saja yang telah dilakukan oleh usaha ini selama memasarkan produknya, variabel ini berupa:

1. Produk, terdiri dari:

a. Klasifikasi produk 

b. Jumlah produk yang dihasilkan
c. Penggunaan merk dalam pemasaran
d. Packing dan labelling

2. Harga, berupa:

a. Metode penetapan harga

b. Tujuan penetapan harga

3.Distribusi, berupa:
a. Saluran tataniaga yang digunakan
b. Margin tataniaga
c. End consumer
d. Transportasi
e. Penggudangan

4. Promosi, berupa:

Pernah atau tidak pernah dilakukannya promosi berikut bentuk promosi yang pernah dilakukan bila pernah melakukan promosi

B. Untuk membantu merumuskan strategi digunakan analisa SWOT, sehingga diperoleh kondisi internal dan eksternal usaha. Variabelvariabel di atas digunakan sebagai variabel lingkungan internal pemasaran usaha dan dilengkapi dengan variabel-variabel lain yang berfungsi sebagai variabel lingkungan eksternal usaha. Variabel-variabel yang tergolong variabel eksternal usaha tersebut adalah sebagai berikut:

1. Aspek pelanggan,meliputi:

a. Jumlah pelanggan

b. Pola hubungan pelanggan dan usaha

2. Aspek pesaing,meliputi:

a. Jumlah pesaing yang ada terutama pesaing lokal

b. Selisih harga produk yang ditawarkan dengan harga pesaing

c. Terobosan yang dilakukan pesaing dalam mempromosikan produknya
3. Aspek kebijakan pemerintah dalam memasarkan telur, khususnya pemerintah setempat.

\section{Analisa Data}

Penelitian ini merupakan penelitian yang bersifat deskriptif eksploratif yaitu mengungkapkan kondisi pemasaran produk peternak dengan menggunakan variabel di atas dan menganalisanya dengan pendekatan SWOT.

Untuk menjawab tujuan pertama digunakan metode deskriptif eksploratif atas temuan dari variabelvariabel yang digunakan, yang dilengkapi dengan pembahasan menggunakan literatur terkait tentang marketing mix.

Untuk menjawab tujuan kedua digunakan analisa SWOT. Dalam analisa ini varaibel yang telah dikategorikan ke dalam lingkungan internal dan eksternal dianalisa dengan cara mengidentifikasinya, apakah sebuah variabel tergolong variabel S (Strenghs), W (Weaknesses), O (Opportunities) atau $\mathrm{T}$ (Threats).

Kekuatan (Strenghs ) adalah keunggulan sumber, kehandalan produk yang membuatnya lebih kuat dari pesaing yang ada. Kelemahan (Weaknesses) adalah keterbatasan atau kekurangan dalam sumber dan kehandalan produk yang membuat produk lebih lemah dibandingkan pesaingnya. Keduanya tergolong ke dalam lingkungan internal.

Peluang (Opportunities) adalah bebagai kondisi luar usaha yang menguntungkan bagi keberadaan usaha. Dan Ancaman (Threats) adalah faktor lingkungan yang tidak menguntungkan bagi pemasaran produk, dan bersifat sebagai kendala dalam menjalankan pemasaran produk. 
Untuk dapat menganalisa lebih lanjut kebijakan dan stategi yang diambil, maka aspek-aspek yang dianalisa tersebut dimasukkan ke dalam matriks SWOT. Matriks SWOT ini memiliki empat kuadran yang menggambarkan kemungkinankemungkinan strategi yang dapat diambil, yaitu strategi SO, WO, ST, dan WT.

Strategi SO adalah stategi pemasaran dengan memanfaatkan semaksimal mungkin peluang dan kekuatan yang dimiliki dalam pemasaran produk. Strategi WO adalah strategi dengan menganalisa peluang yang terbuka lebar yang dimiliki usaha dengan kondsi keterbatasan usaha yang mempengaruhi pengambilan peluang tersebut. Strategi ST adalah upaya memaksimalkan kekuatan yang dimiliki untuk dapat mengambil peluang pemasaran jangka panjang. Sedangkan strategi WT adalah upaya meminimalkan kelemahan sambil berupaya menghadapi kelemahan usaha yang dimiliki.

Setelah identifikasi dilakukan, maka penulis akan berupaya merumuskan salah satu strategi terbaik bagi pemasaran telur ayam ras pada usaha ini.

\section{Hasil dan Pembahasan}

\section{Profil Perusahaan}

Usaha peternakan ayam ras petelur H. Djarasun mulai dirintis oleh Bapak Haji Djarasun Mangkuto sejak tahun 1983 dengan modal sendiri. Awal berdirinya peternakan ini hanya mempunyai populasi \pm 100 ekor dengan menempati lahan seluas 1 Ha dan dilakukan sebagai usaha sambilan saja.

Pada awal berdirinya hingga sekarang lingkungan tempat usaha peternakan ayam ras $H$. Djarasun yang beralamat lengkap di Dusun Sawah Dangka, Nagari Gadut, Kecamatan Tilatang Kamang ini berada cukup jauh dari pemukiman penduduk sehingga kegiatan usaha tidak meng-ganggu daerah sekitar. Walaupun di-lakukan pengembangan, karena area peternakan cukup luas.

Setelah beberapa tahun berjalan berkat keuletan dan kerja keras, usaha ini sampai sekarang terus bekembang dengan memiliki populasi 29.500 ekor ayam ras petelur dengan produksi yang terus berkembang juga, di mana pada saat ini jumlah ayam produktif yang dipelihara yaitu \pm 23.360 ekor dengan produksi ratarata perhari \pm 18.220 , dan telah memperluas lahan menjadi $2 \mathrm{Ha}$.

H. Djarasun memiliki 14 orang pekerja kandang yang masingmasingnya bertanggung jawab atas 2000-3000 ekor ayam. Dan untuk pemasaran $\mathrm{H}$. Djarasun mempercayakan kepada seorang marketing yang nanti akan melayani para pelanggan yang datang. Di samping pekerja kandang dan marketing tadi perusahaan juga dibantu oleh seorang dokter hewan.

Wilayah pemasaran untuk produksi telur dilakukan umumnya dalam kota Bukittinggi, Padang Luar, dan Padang Panjang. Di mana perusahaan memiliki pedagang grosir pada masing-masing daerah tadi, yang merupakan pelanggan yang membeli telur dalam jumlah banyak, di samping pedagang pengecer yang berada di sekitar daerah perusahaan.

Pada lingkungan peternakan $\mathrm{H}$. Djarasun persaingan tidak begitu menonjol dalam pengembangan usaha karena pemasaran hasil peternakan ini sudah mempunyai pasaran tertentu, lagi pula peternak lain yang mengelola usaha yang sama tidak banyak dan peternak yang ada juga 
merupakan keluarga dari $\mathrm{H}$. Djarasun, sehingga persaingan yang ada tidak tampak dengan jelas.

Untuk memperlancar proses jual beli $\mathrm{H}$. Djarasun membuka sebuah kios di depan kandangnya, namun telur yang dijual di kiosnya itu tidak hanya telur produksi H. Djarasun, tapi telur produksi peternakan keluarganya juga dipasarkan di kios itu.

Pada usaha peternakan ayam ras petelur yang menjadi produk (output) adalah telur antara lain bibit/DOC, pakan termasuk bahan baku pakan, vaksin dan obat-obatan dan lain-lain.

Bibit ayam ras petelur yang dipelihara pada usaha peternakan ayam ras petelur $\mathrm{H}$. Djarasun adalah Lohman-brown, sejak tahun 1993. Pernah mencoba memelihara bibit Isa, AA Brown dan Decalb, namun menurut pengelola produksinya tidak memuaskan. Alasan memelihara Lohman Brown, karena Lohman mempunyai keistimewaan antara lain : Produksi $50 \%$ dicapai pada umur 152-158 hari, puncak produksi 90-93 $\%$, warna kulit telur coklat dan kuat, daya hidup selama periode pertumbuhan 97-98 \% dan periode produksi 94-96 \%, konsumsi makanan pada periode produksi perekor perhari 105117 gr. Menurut Satyawibawa \& Setyowari (2000), dalam memilih bibit yang baik dapat dilihat pada brosur atau booklet yang dikeluarkan pembibit, biasanya daftar prestasi bibit ayam yang diperhatikan meliputi produksi telur dan konsumsi ransum. Dari tahun 1993 sampai 2003, pemesanan bibit dilakukan melalui PS. SUBUR Payakumbuh, bibit yang dipesan didatangkan dari Medan.

Untuk kebutuhan pakan ayam, $\mathrm{H}$. Djarasun melakukan penggilingan pakan sendiri. Pakan yang dibu- tuhkan adalah $2700 \mathrm{~kg} / \mathrm{hari}$ untuk 23.360 ayam. Sesuai pendapat Suharno (1995), peternakan yang mampu melakukan efisiensi penggunaan pakan adalah peternakan yang bisa melakukan pembuatan pakan sendiri agar biaya dapat ditekan.

Bahan-bahan baku pakan yang dibutuhkan dalam susunan ransum pakan yang digiling antara lain, jagung, dedak, ikan asin, tepung ikan, bungkil kelapa, konsentrat, tepung batu, rhodiamik $\mathrm{CF} 3$ dan ditambahkan sedikit obat lalat. Dalam pemberian makanan $H$. Djarasun menyesuaikan dengan rekomendasi standar konsumsi bibit Loghman Brown. Di mana pada periode produksi diberikan pakan 105-117 gram per ekornya. Menurut Rasyaf (1990) pemberian ransum pada ayam ras petelur, khususnya mengikuti standar yang diberikan pembibitnya. Standar pemberian ransum ini pasti ada pada pembibit dan setiap peternak yang membeli DOC dari pembibit, pasti akan diberikan standar.

Pakan untuk ayam bibit memakai pakan jadi, untuk menghindari resiko. Ini sesuai dengan pendapat Abidin (2003), untuk mengurangi resiko sebaiknya pakan yang diberikan kepada DOC adalah pakan yang direkomendasikan oleh perusahaan penghasil DOC, karena begitu spesifiknya kebutuhan pakan ayam ras petelur masa DOC ini.

\section{Kebijakan Pemasaran}

\section{Kebijakan Produk}

Produk yang dihasilkan peternakan H. Djarasun berupa telur, pakan ternak, pupuk dan ayam afkir. Dilihat dari produksi dan populasi ayam ras petelur H. Djarasun ini bisa dikatakan telah mampu mencapai target. Di mana Hen Day produksi 
peternakan ini mencapai $78 \%$. Menurut Rasyaf (1990) tingkat keberhasilan seorang peternak dalam produksi ayam petelur dapat dilihat dari Hen Day yang dicapai, dan apabila Hen Day mencapai $80 \%$ berarti nilai yang dicapai peternak sudah baik sekali. Ini dapat dilihat dari Tabel 3.

Pakan ternak yang dihasilkan oleh H. Djarasun ini khusus untuk memenuhi kebutuhan peternakan ini saja. Produksi pakan ternak yang dihasilkan sebenarnya bisa saja dipasarkan, tetapi hal ini tidak dilakukan karena itu bukan tujuan dari peternakan ini. Produksi dan kebutuhan pakan ternak di lingkungan peternakan dianggap telah cukup dan walaupun krisis melanda, usaha ini tidak mengalami kekurangan pakan. Adapun kebutuhan pakan di peternakan ini dalam sebulan membutuhkan sebanyak 85 ton. Ditambah produksi pakan untuk ayam periode starter dan grower, sehingga total produksi pakan ternak yaitu sebesar 90 ton/bulan.

Jangkauan pasar dari produk yang dihasilkan antara lain :

a. Telur: Jangkauan pasarnya adalah langsung ke konsumen, perantara, dll.

b. Ayam afkir: Jangkauan pasarnya adalah para pedagang ayam potong c. Pakan ayam : Khusus untuk pakan ayam tidak untuk dipasarkan karena hanya untuk pemenuhan kebutuhan perusahaan saja.

d. Pupuk kandang : Jangkauan pasarnya adalah untuk petani tanaman pangan.

Seperti terlihat pada Tabel 2. Dari tabel di atas dapat dilihat, bahwa produk utama yang dihasilkan peternakan ini dikelompokkan menjadi dua yaitu telur utuh dan telur retak, di mana masing-masingnya telah memiliki pasar tersendiri.

Produk berupa telur ayam ras ini kualitasnya bersifat homogen atau standar. Dalam sistem penjualan yang biasa dilakukan oleh para peternak, ada yang melakukan pembagian /pembedaan harga berdasarkan besar kecil telur/sortir (kecil. Menengah, jumbo/super) ada juga secara remban artinya tidak dibedakan produk/telur berdasarkan ukuran dalam melakukan penjualan. Sedangkan menurut Sima mora (2001), yang perlu diperhatikan dalam hal produk yaitu variasi produk, kualitas produk, disain produk, kemasan, adanya jaminan, pelayanan tambahan, dan menerima pengembalian produk bila terjadi masalah. Hal ini hampir tidak ada dilakukan oleh peternakan $H$. Djarasun dalam pemasaran produknya. Peternak lain di daerah ini pun, tidak memperhatikan hal tersebut, karena

Tabel 3. Populasi dan Produksi Ayam Ras Petelur H. Djarasun Mangkuto

\begin{tabular}{|c|c|c|c|}
\hline Tahun & $\begin{array}{c}\text { Jumlah Ayam } \\
\text { Produktif } \\
\text { (ekor) }\end{array}$ & $\begin{array}{c}\text { Jumlah Ayam } \\
\text { Dipelihara } \\
\text { (ekor) }\end{array}$ & $\begin{array}{c}\text { Produksi Rata-rata } \\
\text { per Hari } \\
\text { (butir) }\end{array}$ \\
\hline 2001 & 12.780 & 15.980 & 10.032 \\
2002 & 17.252 & 20.655 & 13.715 \\
2003 & 21.110 & 25.145 & 16.677 \\
2004 & 23.360 & 29.560 & 18.220 \\
\hline
\end{tabular}

Sumber : Data Perusahaan H. Djarasun, 2005 
Tabel 4. Jangkauan Pasar Produk pada Peternakan H. Djarasun

\begin{tabular}{|c|c|c|c|c|}
\hline No & $\begin{array}{c}\text { Produk yang } \\
\text { Dihasilkan }\end{array}$ & $\begin{array}{c}\text { Jangkauan } \\
\text { Pasar }\end{array}$ & $\begin{array}{c}\text { Harga } \\
\text { (Rp/butir) }\end{array}$ & $\begin{array}{c}\text { Jumlah } \\
\text { (butir/minggu) }\end{array}$ \\
\hline 1. & $\begin{array}{l}\text { Telur : } \\
\text { - Utuh } \\
\text { - Retak }\end{array}$ & $\begin{array}{l}\text { Konsumen } \\
\text { Perantara : } \\
\text { - Grosir } \\
\text { - P. pengecer } \\
\text { Konsumen } \\
\text { Tukang Kue }\end{array}$ & $\begin{array}{l}450 \\
420 \\
433,3 \\
300 \\
300\end{array}$ & $\begin{array}{l}800-1000 \\
115000 \\
10500 \\
400 \\
800-1200\end{array}$ \\
\hline 2. & Ayam afkir & $\begin{array}{l}\text { Pedagang } \\
\text { ayam potong }\end{array}$ & Rp.16500/ekor & $\begin{array}{l}\text { Sesuai permintaan } \\
\text { dan persediaan }\end{array}$ \\
\hline 3. & Pakan ternak & $\begin{array}{l}\text { Tidak } \\
\text { dipasarkan }\end{array}$ & & \\
\hline 4. & Pupuk & $\begin{array}{l}\text { Petani } \\
\text { tanaman } \\
\text { pangan }\end{array}$ & $\begin{array}{l}\text { Rp. } 3000 / \\
\text { karung }\end{array}$ & Sesuai permintaan \\
\hline
\end{tabular}

Sumber : Hasil Penelitian 2005

produk telur biasanya menunjukkan kualitas yang relative homogen.

\section{a. Merk}

Usaha ini tidak mempunyai merk khusus, hanya merk H. Djarasun berupa stempel yang ditempel pada kertas telur. Merk H. Djarasun ini dimaksudkan untuk membedakan telur produksi $\mathrm{H}$. Djarasun dengan telur produksi peternakan lain yang sama dipasarkan pada kios milik $\mathrm{H}$. Djarasun sehingga tidak terjadi kesalahpahaman terhadap pelanggan yang datang karena masing-masing perusahaan telah memiliki pelanggan yang tetap.

\section{b. Pengemasan}

Kegiatan pengemasan dilakukan oleh peternakan ini cukup sederhana, yaitu dengan menggunakan kertas telur dan tali plastik. Untuk pedagang grosir yang membeli telur dalam jumlah banyak, maka telur dalam kertas disusun menjadi satu ikatan, di mana satu ikatan terdiri dari 10 kertas telur dan untuk lebih amannya kertas telur bagian atas dan bagian bawah diberi dua lapis.

\section{Kebijakan Harga}

Peternakan ini dalam menetapkan harga menggunakan metode penetapan harga dalam hubungannya dengan pasar, di mana penentuan harga tidak didasarkan pada biaya, tetapi justru harga yang menentukan biaya bagi ternak.

Harga sangat tergantung pada harga pasaran, oleh karena itu harus selalu memperhatikan informasi mengenai harga pasar. Suharno (1995), informasi pasar berguna untuk melakukan upaya menghindari kerugian akibat fluktuasi harga. Biasanya telur mencapai harga tertinggi pada hari raya lebaran, selain itu musim berpengaruh terha- 
Tabel 5. Harga Telur Peternakan H. Djarasun pada Lembaga Tataniaga yang Terlibat

\begin{tabular}{|c|l|c|c|c|}
\hline No & Lembaga Tataniaga & $\begin{array}{c}\text { Jumlah } \\
\text { (orang) }\end{array}$ & $\begin{array}{c}\text { Harga Jual Perusahaan } \\
\text { (Rp/butir) }\end{array}$ & $\begin{array}{c}\% \\
\text { Penjualan }\end{array}$ \\
\hline 1 & Grosir & 4 & 420 & 90,93 \\
2 & Pedagang pengecer & 10 & 433.3 & 8,24 \\
3 & Konsumen langsung & tidak tetap & 450 & 0,82 \\
\hline
\end{tabular}

Sumber: Hasil penelitian 2005

dap harga telur dan harga bahan baku pakan, saat harga bahan baku pakan naik sementara harga telur turun. Harga telur dapat berubah sewaktuwaktu, bisa dalam satu hari atau dua hari harga telur naik atau turun.

Hasil penelitian menunjukkan bahwa harga telur yang dijual $\mathrm{H}$. Djarasun pada masing-masing lembaga yang terlibat adalah seperti terlihat pada Tabel 5.

Harga jual telur peternakan ini pada tingkat grosir, pengecer, dan konsumen terlihat berbeda-beda, di mana harga yang ditawarkan pada pedagang grosir lebih rendah dari harga yang ditawarkan pada pedagang pengecer dan konsumen. Perbedaan harga yang ditawarkan oleh H. Djarasun di sini tergantung pada jumlah telur yang dibeli oleh masing-masing lembaga pemasaran, karena grosir membeli dalam jumlah yang jauh lebih banyak dibanding pengecer dan konsumen langsung, maka grosir mendapat harga sedikit lebih rendah dibanding yang lain.

\section{Kebijakan Distribusi}

\section{a. Saluran Pemasaran}

Lembaga-lembaga yang terkait dengan pemasaran telur di peternakan H. Djarasun ini sangat menentukan lancarnya pemasaran. Lembaga pemasaran pada peternakan ini terdiri dari produsen yaitu pihak $\mathrm{H}$. Djarasun, pedagang perantara yang terdiri dari pedagang grosir, pedagang pengecer, dan juga konsumen atau pihak pemberi jasa.

Hasil penelitian menunjukkan bahwa terdapat tiga saluran pemasaran telur di perusahaan ini, di antaranya adalah sebagai berikut :

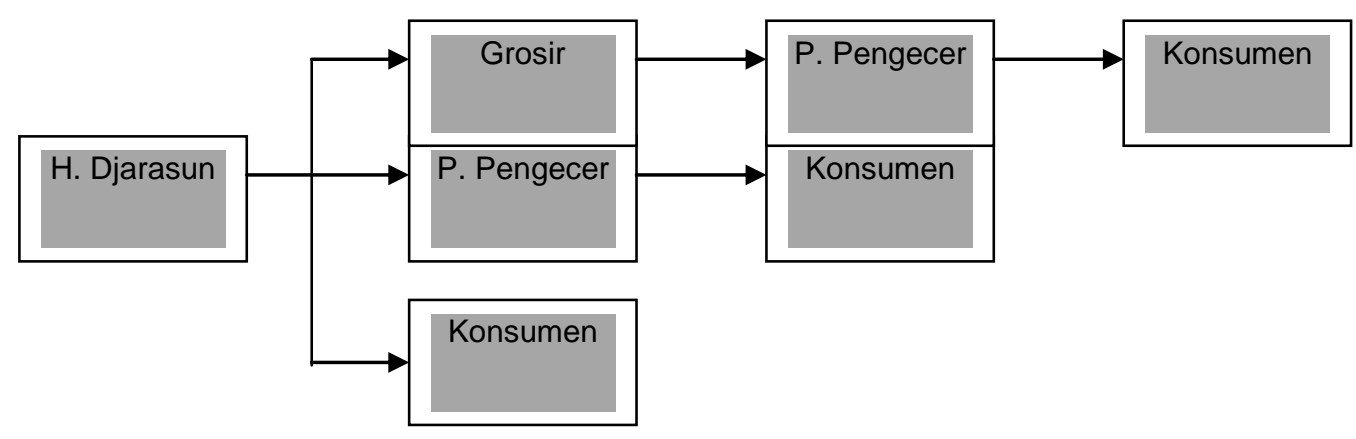

Gambar 1 : Saluran Pemasaran Produk Peternakan H. Djarasun 
Hal ini sesuai dengan pendapat Swasha dan Irawan (1983) yang berpendapat bahwa untuk pemasaran barang konsumsi itu terdapat beberapa macam saluran.

Pedagang Pengecer. Pedagang pengecer adalah seorang pedagang yang melakukan penjualan telur ke konsumen langsung. Setelah dilakukan penelitian di peternakan ini pedagang pengecer yang datang adalah para pedagang-pedagang yang rata-rata memiliki warung baik yang berada di sekitar peternakan, maupun yang datang dari tempat lain dan secara rutin datang ke peternakan ini yaitu sebanyak 10 orang. Kebanyakan para pedagang pengecer membeli telur ke peternakn H. Djarasun sebanyak \pm 300 butir dan mereka akan datang lagi dua atau tiga hari setelah itu, bahkan ada yang setiap hari. Dan penentuan harga ke konsumen antara mereka adalah berbeda-beda ini disesuaikan dengan biaya yang mereka keluarkan.

Pedagang pengecer ternyata sangat berperan dalam memasarkan telur di peternakan $\mathrm{H}$. Djarasun. Hal ini dapat dilihat dari rutinitas mereka yang selalu datang ke peternakan untuk membeli telur dan menjualnya ke konsumen. Walaupun jumlah telur yang mereka beli tidak sebanyak yang dibeli di grosir, peran mereka cukup besar bagi peternakan ini, misalnya saja dari segi harga per butir, mereka mampu membeli telur dengan harga 433,3/butir. Berarti Rp.13 lebih tinggi dibandingkan dengan harga yang dibayarkan oleh grosir. Ini jelas lebih menguntungkan bagi $\mathrm{H}$. Djarasun, tetapi kelemahan pedagang pengecer ini adalah mereka tidak mampu membeli dalam jumlah yang banyak atau sama dengan yang dibeli grosir. Oleh karena itu, pihak peternakan lebih memprioritaskan ke pedagang grosir.

Grosir. Grosir secara tetap membeli telur ke peternakan $H$. Djarasun adalah mereka yang membeli telur dalam jumlah banyak yaitu rata-rata 8275 butir setiap kali membeli dan ada juga yang membeli telur tersebut lebih dari satu kali seminggu, tergantung pemintaan pasar. Kemudian telur-telur itu mereka jual lagi ke pedagang pengecer.

Tabel 6. Jumlah Pembelian Telur Pedagang Pengecer pada Peternakan H. Djarasun

\begin{tabular}{|l|l|l|c|}
\hline No & \multicolumn{1}{|c|}{ Nama } & Tempat Dijual & $\begin{array}{c}\text { Jumlah Pembelian } \\
\text { (Butir/Pembelian) }\end{array}$ \\
\hline 1 & Eni & Gadut & 300 \\
2 & Mardiah & Gadut & 300 \\
3 & Ida & Sanjai & 300 \\
4 & Yetti & Ipuah Mandiangin & 500 \\
5 & As & Kapau & 300 \\
6 & Edi & Kapau & 300 \\
7 & Shaleh & Kapau & 300 \\
8 & Ice & Empat Angkat & 500 \\
9 & In & Pakan Kamis & 500 \\
10 & Mur & Pakan Kamis & 300 \\
\hline
\end{tabular}

Sumber : Hasil Penelitian 2005 
Tabel 7. Jumlah Pembelian Telur oleh Pedagang Grosir pada Peternakan H. Djarasun

\begin{tabular}{|l|l|l|l|}
\hline No & Nama & Tempat dijual & $\begin{array}{l}\text { Jumlah Pembelian } \\
\text { (Butir/Pembelian) }\end{array}$ \\
\hline 1 & Anton & Padang Panjang & 12000 \\
2 & Karya Muda & Padang Luar & 10500 \\
3 & Lis & Bukittinggi & 4500 \\
4 & Nal & Bukittingi & 6000 \\
\hline
\end{tabular}

Sumber : Hasil penelitian 2005

Pedagang grosir yang datang ke peternakan H. Djarasun adalah sebanyak empat orang dan mereka adalah langanan tetap bagi peternakan H. Djarasun. Harga telur yang ditawarkan adalah sebesar Rp. 420/butir.

Konsumen Langsung. Setelah dilakukan penelitian, ternyata konsumen langsung mengambil bagian sebesar $0,82 \%$ dari produksi telur pada peternakan H. Djarasun. Mereka adalah masyarakat yang ada di lingkungan daerah sekitar peternakan. Walaupun jumlah yang mereka beli tidak banyak karena hanya untuk kebutuhan mereka sekeluarga saja. Tetapi bagi peternakan kehadiran mereka ini cukup berarti karena walaupun jumlah yang mereka beli sedikit tetapi harga yang dibayarkan oleh mereka cukup tinggi, yaitu Rp. 450/butir. Selain membeli yang utuh, mereka juga sering membeli telur retak seharga Rp. 300/butir.

Selain dengan ketiga saluran tersebut pada peternakan H. Djarasun pemasaran telur juga melalui beberapa jalur lain yaitu adanya kerja sama dengan tukang kue. Di mana konsumen dari pihak tukang kue ini cenderung untuk membeli telur pecah/retak dan dalam seminggu mereka rutin datang. Hal ini juga sesuai dengan pendapat Rasyaf (1990) bahwa selain melalui pengecer, grosir, pemasaran langsung, melalui pedagang pengumpul, kerja sama dengan pabrik makanan, pabrik roti sangat dianjurkan untuk dijajaki.

\section{b. Margin Pemasaran}

Margin Pemasaran adalah perbedaan harga pada tingkat konsumen dengan harga di tingkat produsen. Sebaran harga ini mencakup semua biaya pemasaran yang dikeluarkan dan keuntungan yang diperoleh pedagang.

Tabel 7, 8, 9 adalah tabel yang menunjukkan biaya dan keuntungan pada masing-masing saluran pemasaran telur di peternakan H. Djarasun. 
Tabel 8. Jumlah Pembelian Telur pada Peternakan H. Djarasun Masing-masing Lembaga Pemasaran (Produksi/hari)

\begin{tabular}{|c|l|c|c|c|}
\hline No & Lembaga Pemasaran & $\begin{array}{c}\text { Jumlah } \\
\text { Pembelian }\end{array}$ & Harga/butir & \% Penjualan \\
\hline 1 & Grosir & 16.550 & 420 & 90,93 \\
2 & Pedagang pengecer & 1.500 & 433.3 & 8,24 \\
3 & Konsumen langsung & 150 & 450 & 0,82 \\
\hline
\end{tabular}

Sumber : Hasil Penelitian 2005

Tabel 9. Margin Biaya dan Keuntungan pada Pemasaran Telur Ayam Ras H. Djarasun pada Saluran Pertama ( H. Djarasun $\rightarrow$ Grosir $\rightarrow$ P. Pengecer $\rightarrow$ Konsumen )

\begin{tabular}{|c|c|c|c|c|}
\hline No & Lembaga Tataniaga & $\begin{array}{c}\text { Penerimaan } \\
\text { (Rp/butir) }\end{array}$ & $\begin{array}{c}\text { Biaya } \\
\text { (Rp/butir) }\end{array}$ & $\begin{array}{c}\text { Keuntungan } \\
\text { (Rp/butir }\end{array}$ \\
\hline 1 & $\begin{array}{l}\text { Peternak (H. Djarasun) } \\
\text { Pembelian kertas telur } \\
\text { Pembelian tali plastik } \\
\text { Harga jual }\end{array}$ & 420 & $\begin{array}{l}6,67 \\
0,99 \\
7,66 \\
\end{array}$ & 412,34 \\
\hline 2 & $\begin{array}{l}\text { Grosir } \\
\text { Harga jual } \\
\text { Harga beli } \\
\text { Transportasi } \\
\text { Pembelian tali plastik } \\
\text { Margin }\end{array}$ & $\begin{array}{l}450 \\
30\end{array}$ & $\begin{array}{l}420 \\
1,39 \\
1,05 \\
2,44\end{array}$ & 27,56 \\
\hline 3 & $\begin{array}{l}\text { Pedagang pengecer } \\
\text { Harga jual } \\
\text { Harga beli } \\
\text { Transportasi } \\
\text { Pembelian plastik } \\
\text { Margin }\end{array}$ & 500 & $\begin{array}{l}450 \\
4,22 \\
3,66 \\
7,88\end{array}$ & 42,12 \\
\hline
\end{tabular}

Sumber : Hasil Penelitian 2005 
Tabel 10. Margin Biaya dan Keuntungan pada Pemasaran Telur Ayam Ras H. Djarasun pada Saluran Kedua ( H. Djarasun $\rightarrow$ P. Pengecer $\rightarrow$ Konsumen )

\begin{tabular}{|l|l|c|c|c|}
\hline No & \multicolumn{1}{|c|}{ Lembaga Tataniaga } & $\begin{array}{c}\text { Penerimaan } \\
\text { (Rp/butir) }\end{array}$ & $\begin{array}{c}\text { Biaya } \\
\text { (Rp/butir) }\end{array}$ & $\begin{array}{c}\text { Keuntungan } \\
\text { (Rp/butir }\end{array}$ \\
\hline 1 & Peternak (H. Djarasun) & & & \\
& Pembelian kertas telur & & 6,67 & \\
& Pembelian tali plastik & 433,3 & 8 & 425,3 \\
& Harga jual & & & \\
& Pedagang pengecer & 500 & & \\
& Harga jual & & 433,3 & \\
& Harga beli & & 4,99 & \\
& Transportasi & & 3,53 & \multirow{2}{*}{58,18} \\
& Pembelian plastik & 66,7 & 8,52 & \\
& Margin & & & \\
\hline
\end{tabular}

Sumber : Hasil Penelitian, 2005

Tabel 11. Margin Biaya dan Keuntungan pada Pemasaran Telur Ayam Ras H. Djarasun pada Saluran Ketiga ( H. Djarasun $\rightarrow$ Konsumen )

\begin{tabular}{|l|l|c|c|c|}
\hline No & \multicolumn{1}{|c|}{ Lembaga Tataniaga } & $\begin{array}{c}\text { Penerimaan } \\
(\mathrm{Rp} / \mathrm{butir})\end{array}$ & $\begin{array}{c}\text { Biaya } \\
(\mathrm{Rp} / \mathrm{butir})\end{array}$ & $\begin{array}{c}\text { Keuntungan } \\
\text { (Rp/butir }\end{array}$ \\
\hline 1 & Peternak (H. Djarasun) & & & \\
& Pembelian kertas telur & 450 & 6,67 & \\
& Harga jual & 450 & & 443,33 \\
\hline
\end{tabular}

Sumber : Hasil Penelitian, 2005

Berdasarkan Tabel 7 dan 8 di atas terlihat adanya perbedaan margin pemasaran dari kedua saluran pemasaran telur ayam ras di peternakan $\mathrm{H}$. Djarasun. Hal ini sesuai dengan pendapat Azzaino (1981) bahwa margin pemasaran dapat berubahubah dari waktu ke waktu dan dapat pula berbeda-beda untuk lembaga pemasaran yang melakukan beraneka ragam kegunaan terhadap barang dan jasa. Pada saluran pemasaran I margin pemasarannya adalah sebesar Rp.80/butir, sedangkan pada saluran pemasaran II margin pemasarannya adalah sebesar 66,7/butir. Terjadinya perbedaan margin pemasaran ini disebabkan oleh panjang pendeknya saluran pemasaran, perbedaan jumlah biaya yang dikeluarkan oleh pedagang serta keuntungan yang diambil pedagang sebagai balas jasa. Margin yang didapat oleh pedagang grosir lebih kecil dari margin yang didapat oleh pedagang pengecer, hal ini wajar terjadi karena pedagang grosir menjual telur dalam jumlah yang besar sehingga modal yag mereka tanam dapat kembali dengan cepat sedangkan para pengecer hanya menjual dalam jumlah yang kecil, sehingga modal yang mereka tertanam dalam waktu yang agak lama.

Jika dilihat dari bagian yang diterima peternak, maka bagian yang diterima peternak rata-rata dari kedua saluran pemasaran adalah sebesar 
$85,33 \%$. Bagian yang diterima peternak ini dapat dikatakan sudah cukup tinggi, karena menurut Rasyaf (1996) menyatakan bahwa peternak minimal harus memperoleh bagian 50 $\%$ dari harga yang dibayarkan konsumen akhir.

Semakin pendek saluran pemasaran yang digunakan maka bagian yang diterima peternak akan semakin besar. Pada saluran 1 memperlihatkan bagian yang diterima peternak lebih kecil, karena pada saluran ini lebih banyak pedagang perantara yang ikut serta dalam proses penyaluran telur ke konsumen. Sehingga tentu saja masing-masing pedagang tersebut mengeluarkan biaya dan akan mengambil keuntungan sebagai balas jasa. Hal ini sesuai dengan pendapat Azzaino (1981) yang menyatakan bahwa bagian yang diterima peternak akan lebih rendah jika jumlah pedagang perantara bertambah panjang.

Biaya pemasaran yang dikeluarkan peternak/ H. Djarasun adalah dari biaya pembelian kertas telur seharga Rp. 200 untuk 30 butir telur. Jadi untuk sebutir telur dikeluarkan biaya sebanyak Rp. 6,67/butir.

Sedangkan biaya pemasaran pada saluran pertama yang dikeluarkan oleh grosir adalah sebesar Rp. 2,44/ butir, biaya yang dikeluarkan oleh pedagang pengecer di saluran pertama adalah Rp. 7,88/butir dan pedagang pengecer di saluran dua yaitu sebesar Rp. 8,52/butir. Tingginya biaya yang dikeluarkan oleh pedagang pengecer di saluran dua adalah karena banyakya telur yang dibeli sedikit dari grosir dan harga beli mereka pada peternakan $\mathrm{H}$. Djarasun berbeda.

Sedangkan keuntungan yang diterima pihak peternakan adalah berbeda-beda di tiap-tiap saluran pemasaran, yaitu pada saluran pertama mendapat keuntungan sebesar Rp. 412,34/butir telur, pada saluran kedua didapat keuntungan sebesar Rp. 425,3/butir, dan pada saluran ketiga peternakan mendapat keuntungan Rp. 443,33/butir telur. Keuntungan yang didapat ini adalah keuntungan dari pemasaran telur saja dan biaya yang dikeluarkan belum termasuk biaya produksi.

Dan pihak perantara yaitu grosir mendapat keuntungan sebesar Rp. 27,56/butir telur dan saluran kedua pedagang pengecer mendapat sebesar Rp. 58,18/butir.

\section{c. Pengangkutan}

Pengangkutan berarti bergeraknya atau pemindahan barang-barang dari tempat produksi ke tempat di mana barang-barang tersebut akan dipakai. (Saefuddin dan Hanafiah, 1983).

Dari hasil penelitian diperoleh bahwa kegiatan pengangkutan telur dilakukan oleh pedagang grosir dan pedagang pengecer yang datang ke kios sehingga transportasi ditanggung oleh para pedagang tersebut. Namun, jika para pedagang tadi memiliki masalah, sehingga meminta untuk diantar maka pihak $H$. Darasun bersedia untuk mengantar. Tapi pengantaran ini sangat jarang sekali terjadi. Peternakan H. Djarasun memiliki dua buah mobil L-300 pick up yang selain digunakan untuk mengantar telur kepada pelanggan yang meminta tadi, mobil juga sering digunakan untuk pengangkutan bahan-bahan pakan dari petani tanaman pangan.

Pengangkutan hasil-hasil peternakan sifatnya cepat dan mudah rusak, sehigga memerlukan kecepatan dan perawatan selama diperjalanan. Menurut Saefuddin dan Hanafiah (1983) kecepatan pengangkutan sa- 
ngat penting dalam tataniaga hasil perikanan, sebab kalau terlambt ada dua resiko yang disebabkan pertama turunnya harga barang di pasar yang dituju, dan kedua resikonya merosotnya kualitas barang. Begitu juga dalam tataniaga hasil peternakan, kecepatan pengangkutan sangat penting agar tidak menimbulkan resiko terhadap komoditi yang akan dijual. Kegiatan pengangkutan juga termasuk fungsi pengadaan fisik dalam fungsi pemasaran.

\section{d. Penggudangan}

Penggudangan termasuk ke dalam fungsi pengadaan fisik dalam fungsi pemasaran. Di mana H. Djarasun memiliki dua jenis gudang, yaitu untuk penyimpanan telur dan untuk penyimpanan bahan pakan.

Untuk penyimpanan telur, kegiatan penggudangan yang satu ini bisa dikatakan tidak ada, karena hanya untuk menempatkan telur yang baru sja dikumpulkan oleh pegawai kandang untuk dilakukan penyortiran (yang kecil dan retak dipisah dari telur yang normal) sebelum dibawa ke kios untuk dijual, sedangkan $\mathrm{H}$. Djarasun tidak pernah mengalami penumpukan telur sebelumnya.

Sedangkan gudang yang satu lagi digunakan untuk menyimpan bahanbahan pakan sekaligus tempat pengolahannya.

\section{Kebijakan Promosi}

Unsur promosi yang dilakukan peternakan $\mathrm{H}$. Djarasun lebih bersifat pendekatan terhadap pembeli potensial. Sampai saat ini belum ada program promosi yang betul-betul terprogram dengan baik, dikarenakan usaha promosi tidak begitu diperlukan dalam usaha memasarkan produknya.

\section{Analisis Lingkungan Peternakan H. Djarasun}

\section{Analisis Lingkungan Internal}

Kegiatan pemasaran memegang peranan yang sangat penting dalam sebuah usaha, walaupun perusahaan berhasil mengembangkan atau menciptakan suatu produk yang berkualitas tinggi, telah menentukan harga yang pantas serta promosi yang gencar, namun hal tersebut akan siasia apabila pelanggan sulit untuk mendapatkan produk yang dihasilkan oleh produsen.

Produksi telur peternakan $\mathrm{H}$. Djarasun ini dipasarkan di daerah Bulittinggi, Padang Luar dan Padang Panjang melalui pedagang-pedagang grosir yang telah lama menjadi langganan mereka, di samping pedagang grosir yang membeli dalam jumlah banyak, peternakan ini juga melayani para pedagang pengecer dan konsumen rumah tangga yang berada di sekitar daerah peternakan. Di mana harga yang ditawarkan pada setiap lembaga pemasaran yang terlibat adalah berbeda-beda. Waktu pembelian bagi pedagang-pedagang yang menjadi langganan yaitu mulai dari pukul 13.00 WIB sampai 19.30 WIB karena pekerja melakukan pemungutan telur sekitar pukul 12.00 WIB.

Dalam menghadapi tabrakan permintaan, di mana pedagang grosir membeli dalam jumlah banyak, maka H. Djarasun membuat giliran hari pembelian dalam setiap minggunya. Dan sisanya nanti akan diambil oleh pedagang pengecer yang ada di daerah sekitar.

Untuk pengangkutan, biasanya pembeli menggunakan kendaraannya masing-masing (pengangkutan ditanggung oleh pembeli). Namun, jika pelanggan tersebut meminta untuk 
diantar H. Djarasun bersedia untuk mengantarkan. Peternakan ini membuka sebuah kios untuk memperlancar proses jual beli yang ditangani oleh seorang pekerja.

\section{Analisi Lingkungan Eksternal}

\section{(a) Aspek Pelanggan}

Usaha yang menghasilkan suatu produk, setelah menjalani proses produksi dan menghasilkan produk, maka produsen akan memikirkan siapa yang akan membeli atau memakai produk tersebut. Begitu juga dengan ayam ras petelur, peternak biasanya khawatir telur menumpuk di gudang, apalagi telur merupakan produk ternak yang tidak tahan lama. Yang menjadi pelanggan utama pada peternakan ini adalah pedagang grosir terdiri dari Anton (Padang Panjang), Karya Muda (Padang Luar), Lis (Bukittinggi), Nal (Bukittinggi) yang mampu membeli dalam jumlah besar, pedagang pengecer juga memegang peran yang sangat penting, walaupun telur yang mereka beli tidak sebanyak yang dibeli grosir, namun mereka mampu membeli telur Rp.13 lebih tinggi disbanding dengan harga yang dibayarakan oleh grosir. Di mana $\mathrm{H}$. Djarasun mempunyai \pm 10 orang pedagang pengecer yang rutin membeli telur setiap dua hari sekali.

Jika dilihat dari volume permintaan pelanggan akan produk ini, H. Djarasun belum mampu memnuhi jumlah produk yang diinginkan oleh pelanggan, maka dari itu pelanggan mengambil sebagian lagi pada kerabat yang masih berada pada daerah peternakan ini.

\section{(b) Aspek Pesaing}

Kabupaten Agam merupakan salah satu daerah yang mempunyai populasi ternak ayam masih kecil dibandingkan dengan Kabupaten 50 Kota yang pada saat ini dijadikan daerah sentra peternakan. Dari data terakhir Dinas Perternakan tahun 2003 di Kabupaten Agam terdapat 17 rumah tangga pemelihara ayam ras petelur dengan total populasi 79.950 ekor ayam.

Berdasarkan laporan Dinas Peternakan dari keseluruhan jumlah peternak yang ada di Kabupaten Agam, hanya sebagian kecil yang telah mencapai skala besar. Peternakan $\mathrm{H}$. Djarasun termasuk salah satu usaha ayam ras petelur yang dapat dikatan mempunyai posisi yang kuat di tengah persaingan yang ada. Beberapa usaha ayam ras petelur yang berada pada posisi bersaing antara lain H. Dt. Rajo Endah, H. Agustami, H. Rajo Balimo, di mana usaha ayam ras petelur ini adalah usaha dengan skala besar, namun sebagian tidak mengolah pakan sendiri.

Hanya saja yang menjadi masalah yaitu pesaing dari luar daerah seperti Payakumbuh dan Medan yang juga memasarkan produk mereka di daerah ini sehingga dapat mempengaruhi harga dan persaingan dalam mendapatkan pasar.

\section{(c). Kebijakan Pemerintah}

Peternakan ini di Kecamatan Tilatang Kamang dijadikan sebagai contoh dalam pengembangan peternak-peternak kecil oleh Pemerintah Cabang Dinas Peternakan Tilatang Kamang, ini merupakan kesempatan bagi $H$. Djarasun untuk dapat lebih banyak bergerak dalam pengembangan usaha, karena secara tidak langsung artinya peternakan ini mendapat dukungan dari pemerintah.

Menurut H. Djarasun, kebijakan pemerintah yang paling terasa dampaknya adalah dicabutnya subsidi 
dari pemerintah terhadap biaya pakan sejak tahun 1997, karena baiaya pakan merupakan ongkos biaya produksi terbesar. Ada beberapa surat keputusan pemerintah tentang usaha ternak ayam petelur, antara lain, Surat Keputusan Menteri Pertanian Republik Indonesia No. 362/Kpts/ TN/1990, bahwa ada dua kegiatan peternakan yang dapat diusahakan oleh perusahaan peternakan, yaitu pembibitan dan budi daya ternak, Surat Keputusan Jendral Peternakan No. 774/KPTS/DEPTAN/1982 tentang Syarat-Syarat Teknis Perusahaan Peternakan Ayam Petelur atau Ayam Pedaging dan Keputusan Presiden Republik Indonesia Nomor 22 Tahun 1990 tentang Pembinaan Usaha Peternakan Ayam Ras. (Sudaryani \& Santosa, 2003).

Dari hasil analisis Lingkungan di atas, kemudian dikelompokkan berdasarkan kekuatan, kelemahan, peluang dan ancaman.

\section{a. Identifikasi Kekuatan}

1) Integrasi Vertikal adalah kombinasi dari proses-proses produksi, distribusi, penjualan dan proses ekonomi lainnya dalam suatu perusahaan. Sebagai contoh, sebuah perusahaan memiliki sendiri armada penjualan, perusahaan menambang sendiri bahan baku yang akan dibuat menjadi produk akhir, dsb (Porter), 1997. Berdasarkan teori ini, dapat disimpulkan peternakan H. Djarasun melakukan praktek integrasi vertical dengan membuat pakan sendiri, serta melakukan pemasaran langsung. Dan menurut Porter (1997), integrasi vertical dapat memberi manfaat yaitu pencapaian penghematan atau penekanan biaya, dalam produksi, penjualan dan pembelian.

\section{b. Identifikasi Kelemahan}

1) Berperan sebagai penerima harga. Harga ditentukan oleh kekuatan pasar, sehingga peternak tidak dapat meraih keuntungan yang besar, karena dipengaruhi oleh fluktuasi harga telur maupun harga produksi. Peternak tidak dapat menentukan harga berdasarkan anggaran biaya produksi dan tingkat keuntungan.

2) Peternakan belum mampu untuk memenuhi kapasitas produksi, sehingga menyebabkan belum terpenuhinya seluruh permintaan. Hal ini merupakan kelemahan peternakan ini karena belum mampu menjual produk, sesuai dengan jumlah permintaan yang diinginkan pelanggan.

\section{c. Identifikasi Peluang}

1) Hubungan yang baik dengan pelangan. Pelanggan termasuk setia dalam berlangganan dengan H. Djarasun, karena sejak awal samapi sekaran terus berlanjut. Hal ini merupakan suatu peluang karena adanya kepercayaan pelanggan terhadap produk dari peternakan ini.

2) Dukungan dan hubungan baik dari pemerintah daerah. Dengan ditunjuknya $\mathrm{H}$. Djarasun sebagai konsultan bagi peternak kecil yang ada di Kecamatan Tilatang Kamang. Hal ini merupakan kesempatan bagi peternakan 
H. Djarasun dalam melakukan pendekatan-pendekatan untuk dapat melakukan pengembangan usaha.

\section{d. Identifikasi Ancaman}

1) Fluktuasi harga, baik harga telur maupun bibit dan pakan.

2) Dicabutnya subsidi pakan ternak oleh pemerintah.

3) Pelanggan beralih ke pesaing guna memenuhi permintaan yang kurang.

Alternatif Strategi yang Terbentuk dari Analisis SWOT

Untuk menyusun faktor-faktor strategi pemasaran peternakan, maka dapat digunakan matrik SWOT yang dapat menggambarkan dengan jelas bagaimana peluang dan ancaman yang dihadapi dapat disesuaikan dengan kekuatan dan kelemahan yang dimiliki. Dan dari kekuatan-kekuatan yang dimiliki serta ancaman dan peluang dihadapi dapat disusun beberapa alternatif strategi, yang dapat dilihat pada matrik SWOT pada Tabel 12. Dari matrik SWOT tersebut tercipta kemungkinan alternative strategi-strategi yang terbentuk dari keterpaduan Strenghts, Weaknesses, Oportunities, dan Threat dalam bentuk strategi $\mathrm{S}-\mathrm{O}$ strategi, S-T strategi, W-O strategi dan W-O strategi.

Tabel 12. Matriks Analisis SWOT

\begin{tabular}{|c|c|c|}
\hline & \begin{tabular}{l}
\multicolumn{2}{c}{ Kekuatan (S) } \\
1. Integrasi vertical (pengolahan \\
pakan, pemasaran, armada \\
penjualan (S1)
\end{tabular} & \begin{tabular}{ll} 
& \multicolumn{2}{l}{ Kelemahan (W) } \\
1. & $\begin{array}{l}\text { Berperan sebagai } \\
\text { penerima harga } \\
\text { (W1) } \\
\text { 2. }\end{array}$ \\
Belum mampu me- \\
menuhi seluruh per- \\
mintaan pelanggan \\
(W2)
\end{tabular} \\
\hline $\begin{array}{l}\text { Peluang }(\mathbf{O}) \\
\text { 1. Hubungan yang baik } \\
\text { dengan pelanggan, } \\
\text { ada kepercayaan pe- } \\
\text { langgan terhadap pro- } \\
\text { duk dari peternakan } \\
\text { ini (O1) } \\
\text { 2. Dukungan dari peme- } \\
\text { rintah/dinas peter- } \\
\text { nakan daerah (O2) } \\
\text { 3. Permintaan telur yang } \\
\text { cenderung meningkat } \\
\text { karena harga produk } \\
\text { pengganti relatif lebih } \\
\text { mahal dan telur kon- } \\
\text { sumsi semua lapisan } \\
\text { masyarakat (O3) }\end{array}$ & $\begin{array}{l}\text { Alternatif Strategi } \\
\text { Peluang-Kekuatan } \\
\text { 1. Pemberdayaan karyawan untuk } \\
\text { meningkatkan kinerja perusahaan } \\
(\mathrm{O} 1, \mathrm{O} 2, \mathrm{O} 3-\mathrm{S} 1) \\
\text { 2. Memperluas pangsa pasar } \\
(\mathrm{O} 3, \mathrm{O} 4-\mathrm{S} 1, \mathrm{~S} 2, \mathrm{~S} 3) \\
\text { 3. Mengembangkan unit pengolahan } \\
\text { pakan }(\mathrm{O} 2-\mathrm{S} 2, \mathrm{~S} 3) \\
\text { 4. Menjalin hubungan yang lebih } \\
\text { baik dengan para pembeli } \\
\text { khususnya pembeli potensial (O1- } \\
\text { S1) }\end{array}$ & $\begin{array}{l}\text { Alternatif Strategi } \\
\text { Peluang-Kelemahan } \\
\text { 1. } \\
\text { Beroperasi } \\
\text { mungkin, seefisien } \\
\text { mampu sehingga } \\
\text { harga yang berlaku } \\
\text { (W1-O4) }\end{array}$ \\
\hline $\begin{array}{l}\text { Ancaman (T) } \\
\text { 1. Pelanggan Beralih ke } \\
\text { Pesaing Guna Meme- } \\
\text { nuhi Permintaan yang } \\
\text { Kurang (T1) } \\
\text { 2. Fluktuasi harga, baik }\end{array}$ & $\begin{array}{l}\text { Alternatif Strategi } \\
\text { Ancaman Kekuatan } \\
\text { 1. Berusaha mempertahankan pangsa } \\
\text { pasar yang saat ini sudah dikuasai } \\
\text { (T1, S1, S2, S3) } \\
\text { 2. Menambah kapasitas produksi agar }\end{array}$ & $\begin{array}{l}\text { Alternatif Strategi } \\
\text { Ancaman Kelemahan } \\
\text { 1. Berupaya berproduksi } \\
\text { sesuai dengan permin- } \\
\text { taan sehingga pe- } \\
\text { langgan tidak beralih }\end{array}$ \\
\hline
\end{tabular}




\begin{tabular}{|l|l|l|}
\hline $\begin{array}{l}\text { harga telur maupun } \\
\text { harga bibit dan pakan } \\
\text { (T2) }\end{array}$ & $\begin{array}{l}\text { dapat memenuhi permintaan pe- } \\
\text { langgan }(\mathrm{T} 2-\mathrm{S} 1, \mathrm{~S} 2)\end{array}$ & ke pesaing (T2-W2) \\
\hline
\end{tabular}

Sumber : Hasil Penelitian 2005

Alternatif Strategi Peluang-Kekuatan (S-O Strategi)

1) Mengembangkan unit pengolahan pakan, dengan adanya peluang teknologi pengolahan pakan, hubungan yang baik dengan pemasok.

2) Menjalin hubungan yang lebih baik dengan pelanggan, khususnya pelanggan potensial dengan jalan tetap memberikan mutu dan pelayanan yang baik.

Alternatif Strategi PeluangKelemahan (W-O Strategi)

1. Beroperasi seefisien mungkin, sehingga mampu mengikuti harga yang berlaku. Karena peternak hanya berperan sebagai penerima harga, sehingga konsentrasi pada berproduksi seefisien dan seefektif mungkin.

Alternatif Strategi AncamanKekuatan (S-T Strategi)

1. Perlu berusaha mempertahankan pangsa pasar yang telah dikuasai, agar pasar tidak beralih kepada perusahaan pesaing lain.

2. Dengan modal yang dimiliki, perusahaan dapat menambah kapasitas produksi sehingga produksi bertambah dan menutupi permintaan yang kurang.

Alternatif Strategi AncamanKelemahan (W-T Strategi)

1) Berupaya memproduksi, minimal sesuai jumlah permintaan pelanggan sehingga tertutup kemungkinan pelanggan akan beralih ke pesaing.
Berdasarkan hasil analisis lingkungan internal dan eksternal peternakan H. Djarasun yang sangat beragam, dan setelah dilakukan pengelompokan atas dasar kekuatan, kelemahan, peluang dan ancaman maka peternakan H. Djarasun berada pada strategi pengembangan pangsa pasar dengan tetap mempertahankan pasar yang ada, di mana perusahaan harus berusaha memperluas pangsa pasar yang tentunya dengan tetap mempertahankan pangsa pasar yang dikuasai agar tidak beralih ke pesaing. Adapun strategi pilihan yang dapat dilakukan oleh peternakan $\mathrm{H}$. Djarasun yaitu :

1) H. Djarasun harus memikirkan untuk dapat memperluas pangsa pasarnya dengan cara menargetkan pasar mana yang akan dituju, yaitu dengan membuat jaringan distribusi di berbagai daerah untuk meningkatkan daerah pemasaran dan juga $H$. Djarasun dapat melakukan penambahan lembaga pemasaran seperti pedagang pengecer yang mampu membeli dengan harga lebih tinggi, sehigga dengan memperluas usaha ini diharapkan volume penjualan dapat ditingkatkan.

2) Melakukan pengembangan unit pengolahan pakan, dengan SDM serta modal yang besar $\mathrm{H}$. Djarasun dapat meningkatkan pengadaan bahan baku pakan sehingga dapat memproduksi secara optimal bahkan dapat membuka pemasaran pakan pada peternak-peternak yang masih dalam skala kecil yang 
berada di sekitar lingkungan $\mathrm{H}$. Djarasun.

3) Perusahaan tetap mempertahankan pangsa pasar yang saat ini telah dikuasai, dengan cara tetap menjalin hubungan yang baik terhadap pelanggan, khususnya pelanggan potensial agar pelanggan tersebut tidak beralih ke pesaing yang ada. Hubungan yang baik terhadap pelanggan dapat terjalin jika pelayanan yang diberikan tenaga kerja kepada pelanggan sangat memuaskan, sehingga pelanggan merasa nyaman, percaya dan tidak terjadi kekecewaan.

\section{Kesimpulan}

Berdasarkan hasil dan
pembahasan yang diperoleh dari
penelitian ini, didapatkan kesimpulan
sebagai berikut :

1. Kebijaksanaan pemasaran telur pada perusahaan $H$. Djarasun yaitu :

- Kebijaksanaan produk yang diterapkan oleh H. Djarasun meliputi produksi telur yang merupakan produk konsumsi, dengan merk $H$. Djarasun berupa stempel dan pengemasan dilakukan dengan menggunakan kertas telur dan tas plastik.

- Kebijakan harga yang diterapkan dalam menetapkan harga jual adalah dengan metode penetapan harga sesuai harga pasar.

- Dalam kebijaksanaan distribusi $H$. Djarasun menerapkan saluran :

1. H. Djarasun $\rightarrow$ Grosir $\rightarrow$ P. Pengecer $\rightarrow$ Konsumen
2. H. Djarasun $\rightarrow$ P. Pengecer $\rightarrow$ Konsumen

3. H. Djarasun $\rightarrow$ Konsumen Dengan volume penjualan telur terbesar yaitu kepada pedagang grosir dengan persentase 90,93 \% dari produksi perusahaan perhari.

Dan margin yang didapat :

a. Rp. 30/butir pada pedagang grosir

b. Rp. 50/butir pada pedagang pengecer di saluran pertama

c. Rp. 66,7/butir pada pedagang pengecer di saluran dua

- Kebijaksanaan promosi yang diterapkan H. Djarasun hanya bersifat pendekatan terhadap pembeli potensial. Sedangkan kegiatan promosi yang betulbetul terencana belum ada.

2. Alternatif strategi yang diperoleh dari keterpaduan kekuatan, kelemahan, ancaman dan peluang yang dihadapi, yaitu memberdayakan tenaga kerja perusahaan, sehingga lebih produktif dan bekerja optimal melalui pembagian kerja yang proporsional, memperluas pangsa pasar dengan cara mentargetkan pasar mana yang akan dituju, melakukan pengembangan unit pengolahan pakan, sehingga dapat membuka pemasaran pakan pada peternakpeternak yang masih dalam skala kecil, tetap mempertahankan pangsa pasar yang saat ini telah dikuasai dengan cara tetap menjalin hubungan baik terhadap pelanggan.

\section{Saran}

Jika perusahaan meningkatkan jumlah produksi, hendaknya perusahaan lebih meningkatkan penjualan 
pada pedagang pengecer, sehingga perusahaan nantinya tidak terlalu tergantung kepada pedagang grosir.

\section{Daftar Pustaka}

Abidin, Z. 2003. Meningkatkan Produktivitas Ayam Ras Petelur PT. Agromedia Pustaka. Jakarta.

Atmakusuma, Y. 1998. Tata Niaa Peternakan. Universitas Terbuka, Depdikbud, Jakarta.

Azzaino, Z. 1981. Pengantar Tataniaga Pertanian. Departemen Ilmu Sosial Ekonomi pertanian Fakultas Pertanian. Institut Pertanian Bogor. Bogor.

Cravens, D.W. 1998. Pemasaran Strategis. Jilid 2. Edisi 4. Penerbit Erlangga. Jakarta.

Dinas Peternakan. 2002. Data Statistik Peternakan SeSumatera Barat. Disnak, Padang.

Downey, D. W dan Erickson, Steven P. 1992. Manajemen Agribisnis. Penerbit Erlangga. Jakarta.

Jauch, L.R dan William F. Glueck. 1993. Manajemen Strategis dan Kebijakan Perusahaan. Penerbit Erlangga. Jakarta.

Kotler, P. dan Amstrong, Gary J. 1997. Dasar-dasar Pemasaran. Penerbit PT. Prenhallindo. Jakarta.

Kotler, P. 2002. Manajemen Pemasaran (Terjemahan: Hendra Agus, SE, Ak dan Rhony A. Rusli, SE, Ak). Edisi Milenium.
Penerbit PT. Prenhalindo. Jakarta.

Limbong, W.H dan p. Sitorus. 1985. Pengantar Tataniaga Pertanian. Jurusan Ilmu-ilmu Sosial Ekonomi Pertanian. Fakultas Pertanian. IPB. Bogor.

Mubyarto. 1986. Pengantar Ekonomi Pertanian. Cetakan ke-8. Penerbit LP3ES. Jakarta.

Porter, E.M. 1997. Strategi Bersaing, Teknik Menganalisis Industri dan Pesaing. Erlangga. Jakarta.

Rasyaf, M. 1996. Memasarkan Hasil Peternakan. Cetakan Kesatu. Penerbit Penebar Swadaya. Jakarta.

Rasyaf M. 1990. Pengelola Produksi Telur. Penebar Swadaya. Jakarta.

Rasyaf, M. 2003. Manajemen Peternakan Ayam Ras Petelur. Penebar Swadaya. Jakarta.

Saefuddin, A. M. dan Hanafiah. 1983. Tataniaga Hasil Perikanan. Universitas Indonesia Press. Jakarta.

Sastraatmadja, E. 1984. Ekonomi Pertanian Indonesia Masalah, Gagasan dan Strategi. Penerbit Angkasa Bandung. Bandung.

Satyawibawa, F. R. dan Rina N. S. 2000. Agribisnis Peternakan. Penebar Swadaya. Jakarta.

Siagian, S. 1995. Manajemen Strategic. Bumi Aksara. Jakarta. 
Simamora, B. 2001. Memenangkan Pasar dengan Pemasaran Efektif dan Profitabel. Gramedia. Jakarta.

Stanton, W. J. 1996. Prinsip Pemasaran. Jilid 2. Penerbit Erlangga. Jakarta.

Sudaryani, H.S. 2003. Pemeli-haraan Ayam Ras Petelur di Kandang Baterai. Penebar Swadaya. Jakarta.

Sudiyono, A. 2001. Pemasaran Pertanian. Universitas Muhammadiyah Malang Press. Malang.
Suharno, B. 1995. Agribisnis Ayam Petelur. PT Penebar Swadaya. Jakarta.

Supriyono, R. A. dan S. U, Akuntan. 1996. Manajemen Strategis dan Kebijaksanaan Bisnis. BPFEYogyakarta. Yogyakarta.

Swastha, B dan Ibnu S. 1999. Pengantar Bisnis Modern. Edisi Ketiga. Liberty, Yogyakarta.

Swastha, B. dan Irawan. 1983. Manajemen Pemasaran Modern. Liberty, Yogyakarta.

\section{Lampiran 1. Populasi Ayam Ras Petelur Peternak di Kecamatan Tilatang Kamang}

\begin{tabular}{|c|l|c|}
\hline No & \multicolumn{1}{|c|}{ Peternak } & $\begin{array}{c}\text { Jumlah ayam yang dipelihara } \\
\text { (ekor) }\end{array}$ \\
\hline 1 & H. Djarasun & 30000 \\
2 & H. Agustami & 10000 \\
3 & H. Dt. Rajo Endah & 24000 \\
4 & H. Rajo Balimo & 15000 \\
5 & Farlan & 5000 \\
6 & H. Antoni & 5000 \\
7 & Yeni & 4000 \\
8 & Pendi & 5000 \\
9 & Endang & 5000 \\
10 & Datuak & 5000 \\
\hline
\end{tabular}

Sumber : Cabang Dinas Peternakan Tilatang Kamang 2004

Lampiran 2. Besarnya Margin, Biaya dan Keuntungan pada Masing-masing Pedagang Perantara yang Terlibat dalam Pemasaran Telur Ayam Ras di Perusahaan H. Djarasun

\begin{tabular}{|c|l|c|c|c|}
\hline $\begin{array}{c}\text { Saluran } \\
\text { Pemasaran }\end{array}$ & Jenis Pedagang & $\begin{array}{c}\text { Margin } \\
\text { (Rp/butir) }\end{array}$ & $\begin{array}{c}\text { Biaya } \\
(\text { Rp/butir })\end{array}$ & $\begin{array}{c}\text { Keuntungan } \\
\text { (Rp/butir) }\end{array}$ \\
\hline I & Grosir & 30 & 2,44 & 27,56 \\
& Pengecer & 50 & 7,88 & 42,12 \\
\hline & Jumlah & 80 & 10.32 & 69,68 \\
\hline II & Pengecer & 66,7 & 8.52 & 58,18 \\
\hline & Jumlah & 66,7 & 8.52 & 58.18 \\
\hline
\end{tabular}

Sumber : Hasil Penelitian 2004 
Lampiran 3. Margin Pemesanan Telur dan Bagian yang Diterima oleh $\mathbf{H}$. Djarasun

\begin{tabular}{|c|c|c|c|c|}
\hline $\begin{array}{c}\text { Saluran } \\
\text { Pemasaran }\end{array}$ & $\begin{array}{c}\text { Margin } \\
\text { (Rp/butir) }\end{array}$ & $\begin{array}{c}\text { Biaya } \\
\text { (Rp/butir) }\end{array}$ & $\begin{array}{c}\text { Keuntungan } \\
\text { (Rp/butir) }\end{array}$ & $\begin{array}{c}\text { Bagian } \\
\text { Diterima } \\
\text { Peternak (\%) }\end{array}$ \\
\hline I & 80 & 10,32 & 69,68 & $84 \%$ \\
II & 66,7 & 8,52 & 58,18 & $86,66 \%$ \\
\hline
\end{tabular}

Sumber Hasil Penelitian, 2005

Alamat Responden: Rahmat Syafriardi Jurusan Produksi Ternak, Fakultas Peternakan Universitas Andalas, Kampus Limau Manis, Padang Telp. 0751-74208 Fax: 0751-71464, HP: 08126619260

Artikel diterima: 15 Februari 2006, disetujui: 28 Februari 2006 